\title{
Feeding mink (Neovison vison) a protein-restricted diet during pregnancy induces higher birth weight and altered hepatic gene expression in the $F_{2}$ offspring
}

\author{
Connie F. Matthiesen ${ }^{1}$, Dominique Blache ${ }^{2}$, Preben D. Thomsen ${ }^{1}$ and Anne-Helene Tauson ${ }^{1}$. \\ ${ }^{1}$ Department of Animal and Veterinary Basic Sciences, Faculty of Life Sciences, University of Copenhagen, Grønnegårdsvej 3 , \\ DK-1870 Frederiksberg C, Denmark \\ ${ }^{2}$ Faculty of Natural and Agricultural Sciences, School of Animal Biology, University of Western Australia, 35 Stirling Highway, \\ Crawley, Perth, WA 6009, Australia
}

(Received 30 April 2009 - Revised 11 February 2010 - Accepted 12 February 2010 - First published online 25 March 2010)

Malnutrition during foetal life can induce modifications in the phenotype of an individual. The present study aimed to observe effects of low foetal life protein provision on modifications of the phenotype and changes in the progeny of 1-year-old female mink $\left(\mathrm{F}_{1}\right.$ generation) offspring of mothers fed a low-protein diet. Traits studied included reproductive performance, energy and protein metabolism, and key hepatic enzymes associated with glucose homeostasis and metabolic hormones. The $\mathrm{F}_{0}$ generation offspring were fed either a low-protein (14\% of metabolisable energy (ME) from protein - FLP1) or an adequate-protein (29\% of ME from protein - FAP1) diet for the last 17.9 (SD 3.6) d of gestation. The $\mathrm{F}_{1}$ dams were studied at birth and at 1 year of age, during their first reproductive cycle, after maintenance on an adequate diet from birth and thereafter. Metabolic traits during gestation and lactation were largely unaffected by foetal life protein provision, but birth weight in the $\mathrm{F}_{2}$ generation was higher $(P=0 \cdot 003)$ among FLP2 kits than among FAP2 kits. Furthermore, the relative abundance of pyruvate kinase mRNA was significantly $(P=0 \cdot 007)$ lower, and fructose-1,6-bisphosphatase mRNA tended $(P=0.08)$ to be lower in FLP2 foetuses than in FAP2 foetuses, showing some similar difference in the $F_{2}$ generation and $F_{1}$ generation foetuses, suggesting an effect on some hepatic enzymes affecting glucose homeostasis being transmitted from the $F_{1}$ to the $F_{2}$ generation. These findings indicate that even though energy and nitrogen metabolism displayed no effect of protein provision during early life, programming effects still appeared at the molecular level in the following generation.

Metabolic imprinting: Glucose homeostasis: Nitrogen metabolism: Energy metabolism: Quantitative metabolism: Protein restriction: Transgenerational effects

Malnutrition during foetal life might induce structural and functional metabolic changes in offspring, primarily through adaptations aimed towards maximising the utilisation of those nutrients that are available so as to optimise foetal development and survival ${ }^{(1,2)}$. These adaptations are associated with the period during development in which the malnutrition occurs, i.e. whether it occurs during certain sensitive periods of foetal life $\mathrm{e}^{(3)}$. Indeed, it is known that for offspring exposed to a postnatal environment different from that predicted in foetal life, the resulting mismatch can put them at increased risk of developing metabolic and CVD later in life ${ }^{(4)}$. Of considerable interest, however, is the finding that modification and consequences of a period of malnutrition during pregnancy are not necessarily limited to first-generation offspring (i.e. the $F_{1}$ generation), but can be transgenerational ${ }^{(5)}$. Hence, there is evidence that changes in glucose and insulin metabolism and key hepatic enzymes caused by protein restriction during late pregnancy can be transmitted from the $F_{1}$ to the $F_{2}^{(5-8)}$ and $F_{3}$ generations ${ }^{(9)}$ in rats, although the results relating to glucose and insulin metabolism seem to be age and sex specific ${ }^{(10)}$.
More specifically, protein restriction occurring during pregnancy has been found to reduce birth weight, affect glucose homeostasis, elevate blood pressure ${ }^{(2)}$, cause structural changes in the liver of adult rat offspring ${ }^{(11-14)}$ and reduce the islet and $\beta$-cell mass in the endocrine pancreas leading to reduced insulin secretion $^{(15)}$. The outcome of protein restriction during foetal life depends on time of exposure during the pregnancy but also of the diets used, and both contribute to the differences between the different animal studies ${ }^{(2)}$.

The mink (Neovison vison) is a strict carnivore, and a monoestrous, photosensitive seasonal breeder with one annual breeding season. The mating season starts in early March in the Northern Hemisphere and lasts approximately 20-25 d. Ovulation is induced by mating, and a short embryonic diapause delays implantation. Once implantation has taken place, gestation is completed within $31 \mathrm{~d}$ (this is known as true gestation $)^{(16)}$. Foetal growth is minimal during early pregnancy, with the majority of kit growth occurring in late gestation ${ }^{(17)}$. In this respect, mink may provide a potentially useful animal model for studies of interactions between maternal and foetal nutrition as, like rats, mink give birth to altricial young, which

Abbreviations: Fru-1,6- $\mathrm{P}_{2}$ ase, fructose-1,6-bisphosphatase; IGF-1, insulin growth like factor 1; ME, metabolisable energy; PKM 2 , pyruvate kinase. 
allows programming to occur during both foetal and early postnatal life. In addition, as a strict carnivore, its glucose homeostasis regulation shares traits with subjects experiencing obesity, insulin resistance or type 2 diabetes $^{(18)}$.

Furthermore, maternal protein malnutrition could be expected to cause a mismatch between the environment predicted in foetal life and that experienced in postnatal life, because growing mink are usually provided with a high level of protein and energy.

Previous investigations with mink have found that maternal protein restriction reduced birth weight, and induced changes in the gene expression of both fructose-1,6-bisphosphatase (Fru-1,6- $\mathrm{P}_{2}$ ase) and pyruvate kinase $\left(\mathrm{PKM}_{2}\right)$, gluconeogenic and glycolytic enzymes, in foetal hepatic tissue ${ }^{(19)}$. Changes in the gene expression of some hepatic enzymes caused by maternal nutritional status and the possible transmission of induced changes to subsequent generations have, to the best of our knowledge, not yet been investigated in the mink. Presently, consequences of changes induced by maternal nutrition are unknown, but they would be of great interest, because breeding of the subsequent generations might then lead to increased risk of transmitting adverse changes to a large number of animals.

The hypothesis tested in the present study was that 1-year-old adult mink ( $F_{1}$ generation), offspring born to protein-restricted dams ( $\mathrm{F}_{0}$ generation), and only nutritionally challenged in foetal life, transmit phenotypic changes, in foetal hepatic tissue, to their offspring ( $\mathrm{F}_{2}$ generation).

\section{Material and methods}

The experimental procedures followed the guidelines of the European Convention for the Protection of Vertebrate Animals used for Experimental and Other Scientific Purposes as well as Danish national legislation ${ }^{(20)}$.

\section{Animals and housing}

Fifty-six yearling female mink of the standard black genotype $^{(21)}$ were used. A total of twenty-three of this number which had been exposed during foetal life to a low-protein diet (comprising 14\% metabolisable energy (ME) from protein) were assigned to the group referred to by the abbreviation FLP1, where F denotes foetal, LP denotes low protein, and 1 denotes that they were from the $F_{1}$ generation. Besides these thirty-three mink which had been exposed during foetal life to an adequate-protein diet (comprising 29\% ME from protein) were assigned to the group referred to by the abbreviation FAP1, where AP denotes that they were provided with an adequate protein provision (Fig. 1). Mink had been exposed to these two different protein diets for the last 17.9 (SD 3.6) d of foetal life. After parturition, the dams were fed a conventional wet farm feed comprising an adequate protein content, and the kits were fed the same feed from the time they were weaned and thereafter. The yearling females were mated with unrelated males, which had not been exposed to any form of malnutrition, and this commenced on 7th March according to the $1+9$ system $^{(22)}$. Forty-eight dams were used to study the reproductive performance, and to record kit body weight at birth and body weight subsequently every $7 \mathrm{~d}$ until they reached an age of $28 \mathrm{~d}$. Sixteen animals, comprising eight dams from each in utero treatment (FLP1 and FAP1), were used in balance and respiration experiments during the first and last thirds of the true gestation. After parturition, sixteen yearling dams, comprising eight FLP1 and eight FAP1 dams and their offspring (FLP2 and FAP2, where the 2 denotes the $F_{2}$ generation), each with six kits in a litter and having been born within $48 \mathrm{~h}$ of each other, were used in balance and respiration experiments during the second and fourth weeks of lactation. Eight dams were euthanised during late gestation for tissue collection (see below).

The dams used in the balance and respiration experiments were transferred from the experimental farm to an intensive care unit, where they were placed in metabolic cages ${ }^{(23)}$, and were maintained under natural daylight conditions $\left(55^{\circ} \mathrm{N}\right.$ $\left.12^{\circ} \mathrm{E}\right)$ at $15-17^{\circ} \mathrm{C}$.

\section{Diets}

Dams were exposed to either a low-protein diet (14, 51 and $35 \%$ of ME from protein, fat and carbohydrates) or an adequate-protein diet $(29,56$ and $15 \%$ of ME from protein, fat and carbohydrates) during foetal life. The diets consisted of fresh chicken, potato mash powder, oatmeal, fishmeal, sugarbeet pulp, maize starch (gelatinised), maize oil, vitamin and mineral mixture and water. Further details concerning the diets used during foetal life are given elsewhere ${ }^{(19)}$. They were fed a conventional commercial wet diet ad libitum throughout the experiment to evaluate the effect of two different protein diets during foetal life. The diet had the following chemical composition: DM, $351.8 \mathrm{~g} / \mathrm{kg}$; crude protein, $173.9 \mathrm{~g} / \mathrm{kg}$; fat, $59.5 \mathrm{~g} / \mathrm{kg}$; and carbohydrates, $82.4 \mathrm{~g} / \mathrm{kg}$. The diet was produced by Sjællands Pelsdyrfoder A.m.b.a (Stårup, Denmark). crude protein, fat and carbohydrates accounted for 42, 42 and $16 \%$, respectively, of ME.

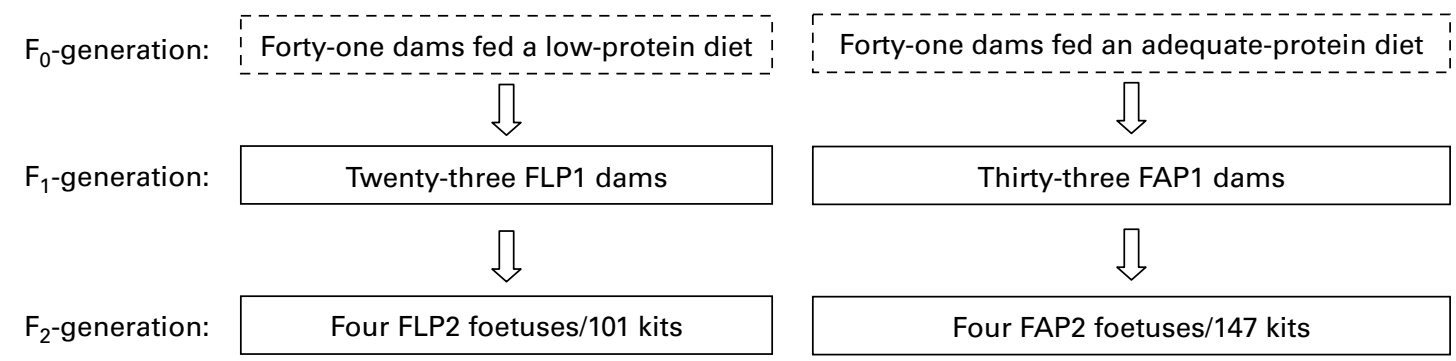

Fig. 1. $F_{0}$ generation fed either a low- or an adequate-protein diet during the last 17.9 (SD 3.6) $d$ of the gestation ${ }^{(18)}$. Their offspring, the $F_{1}$ generation, had been exposed to either a low (FLP1)- or adequate (FAP1)-protein diet during foetal life, and were used in balance and respiration experiments in the present study. The $\mathrm{F}_{2}$ generation offspring (FLP2 and FAP2) were used to study postnatal growth until $28 \mathrm{~d}$ of age. 


\section{Balance and respiration experiments, collection procedures and data recording}

The balance experiments consisted of a $3 \mathrm{~d}$ adaptation period before each collection period, and a $4 \mathrm{~d}$ collection and recording period. The quantitative collection and recording procedures can be found elsewhere ${ }^{(24)}$. The animals were fed ad libitum once every morning. Collection and recording were performed every morning between 09.00 and 11.00 hours. At the end of each balance period, the feed residues, faeces, urine and citric acid rinses were thawed and mixed, and samples were taken for analysis. The animals were measured in the respiration chambers for a period of $22 \mathrm{~h}$ once during each balance period. The respiration experiments were performed by indirect calorimetry in an openair circulation unit. The principles and procedures used for calibration and gas exchange measurements are described elsewhere $^{(25)}$. The dams and kits were weighed at the start and the end of each collection period while in the intensive care unit, otherwise they were weighed once a week, as were the animals used for recordings of body weight.

\section{Blood sample and tissue collection}

Blood samples, from the sixteen dams that participated in the balance and respiration experiments during gestation and lactation, were withdrawn by puncturing the vena cephalica antebrachii $^{(26)}$ at the end of each collection period. The blood was collected in heparinised tubes and centrifuged for $15 \mathrm{~min}$ at $3300 \mathrm{~g}$. Plasma was separated and stored at $-18^{\circ} \mathrm{C}$ until it was analysed for hormones (i.e. insulin growth like factor 1 (IGF-1), insulin and leptin) using RIA. Eight dams (four FLP1 and four FAP1) were used for tissue collection, and for this, they were anaesthetised with $0.2 \mathrm{ml}$ of ketaminol $(50 \mathrm{mg} / \mathrm{ml}$, InterVet International BV, Boxmeer, The Netherlands) and $0.1 \mathrm{ml}$ of Narcoxyl $(20 \mathrm{mg} / \mathrm{ml}$, InterVet International BV) by intramuscular injection. As soon as palpebral and toe-pinch reflexes were absent, blood was sampled by means of heart puncture, and the animals were killed immediately afterwards. Four dams were killed on 20th April (37 (SD 2.1)d after mating) and four dams on 27th April (40 (SD 2.4) d after mating). Foetal and maternal livers were quickly excised, and the body and liver weights of dams and foetuses and the length of foetuses were recorded. Furthermore, the uterus weights were measured and noted. Hepatic tissue from foetuses and dams and subcutaneous adipose tissue from dams were collected and frozen rapidly in liquid $\mathrm{N}_{2}$, and were stored at $-80^{\circ} \mathrm{C}$ until RNA isolation.

\section{Analytical procedures and calculations}

Wet samples of diets and faeces were analysed for DM and nitrogen. Wet samples of the feed residues were analysed for DM and ash only, assuming the organic matter in the residues to be similar to that in the diets. The freeze-dried samples of diets and faeces were analysed for DM, ash, fat and gross energy. Urine and citric acid rinses were analysed for nitrogen content. DM was determined by evaporation at $105^{\circ} \mathrm{C}$ to constant weight. Ash was determined by incineration at $525^{\circ} \mathrm{C}$ for $10 \mathrm{~h}$. Nitrogen was determined by the micro-Kjeldahl technique using a 2020 Digestor at $420^{\circ} \mathrm{C}$ and a 2200 Kjeltec autodistillation unit
(Foss, Höganäs, Sweden). crude protein was calculated as nitrogen $\times 6 \cdot 25$. Fat was determined after hydrolysis with $3 \mathrm{M}-\mathrm{HCl}$ in a Soxtec system 1047 hydrolysing unit tecator (Foss, Höganäs, Sweden), and was extracted with petroleum ether in a Soxtec system 1043 extraction unit (Foss). Gross energy was determined using an adiabatic bomb calorimeter (IKA Calorimeter system, IKA Gmbh \& Co. KG, Staufen, Germany). The equation for heat production can be found elsewhere ${ }^{(27)}$.

The oxidation of protein, carbohydrate and fat was calculated according to the equations given elsewhere ${ }^{(28)}$, and it was validated for the non-protein respiratory quotient where values were above 0.707 and below 1.0. For measurements where the non-protein respiratory quotient was below 0.707 , net oxidation of carbohydrates and fat was corrected to zero, and oxidation of fat was then calculated as the oxidation of fat plus the net oxidation of carbohydrates ${ }^{(25)}$. The milk yield as $\mathrm{g}$ milk/g kit gain and in terms of the content of nitrogen and energy in milk were estimated ${ }^{(29)}$ and used in the balance calculations for lactating dams.

\section{Assessment of gene expression}

Liver $(30-35 \mathrm{mg})$ and adipose tissue $(25-30 \mathrm{mg})$ samples were homogenised in a Dispomix tube with $650 \mu \mathrm{l}$ of trizol using the Medic Tool Dispomix (Medic Tool AG, Zug, Switzerland) followed by a phase separation performed with $120 \mu \mathrm{l}$ chloroform and precipitation of RNA with $500 \mu \mathrm{l}$ isopopanol/600 $\mu \mathrm{l}$ aqueous phase. The RNA was isolated using the SV Total RNA Isolation System (Promega Biotech AB, Stockholm, Sweden). The concentration and purity were estimated on a Thermo Scientific NanoDrop 1000 Spectrophotometer (Thermo Fisher Scientific, Wilmington, DE, USA). Description of the RNA extraction method, transcription into cDNA and estimation of the relative abundance of enzyme mRNA by means of real-time quantitative PCR can be found elsewhere ${ }^{(19)}$. PCR primer oligonucleotides for glucose-6-phosphatase, fructose1,6-bisphosphatase (Fru-1,6- $\mathrm{P}_{2}$ ase), phosphoenolpyruvate carboxykinase and $\mathrm{PKM}_{2}$ were designed from canine mRNA sequences, whereas PCR primer oligonucleotides for leptin and adiponectin were designed from feline mRNA sequences. The chosen reference gene was 18S rRNA; all primers are listed in Table 1. The PCR products of all the primer pairs used were sequenced to confirm product identity. Furthermore, the PCR efficiency was calculated for both the target and reference genes by determining the fitting coefficients of the relative standard curve. The final relative quantification was efficiency corrected.

\section{Plasma measurements}

The hormone concentrations in plasma were analysed using RIA at the University of Western Australia, Perth. Plasma leptin was measured in duplicate by a double-antibody RIA $^{(30)}$. The measurements were made using human leptin, with the first antibody being raised in a rabbit and the second in a donkey. All the samples were processed in a single assay, and the detection limit was $0.06 \mathrm{ng} / \mathrm{ml}$. The assay included six replicates of three control samples containing $0.44,1.24$ and $2.09 \mathrm{ng} / \mathrm{ml}$, which were used to estimate the intra-assay $\mathrm{CV}$ of $5.8,4.8$ and $4.8 \%$, respectively. Plasma insulin was assayed in duplicate using a double-antibody 
Table 1. Sequence of gene-specific RT-PCR primers

\begin{tabular}{|c|c|c|c|c|}
\hline Gene & Forward primer & Reverse primer & Product size (bp) & $\begin{array}{c}\text { GenBank } \\
\text { accession no. }\end{array}$ \\
\hline Glucose-6-phosphatase & 5'CCGAATCTACCTTGCTGCTC $3^{\prime}$ & 5'AGTGTCCACAGGAGGTCCAC3' & 207 & NM102993 \\
\hline Fructose-1,6-bisphosphatase & 5'TACCTGGAAGGCACTTTGCT $3^{\prime}$ & 5'GATGCСТCС ТССТСАСТСТGЗ' & 176 & XM547066 \\
\hline Pyruvate kinase & 5'AAGATCACCCTGGACAATGC3' & 5'GGAAGTCAGCACCTTTCTGC3' & 247 & XM_535531 \\
\hline $\begin{array}{l}\text { Phosphoenolpyruvate } \\
\text { carboxykinase }\end{array}$ & 5'GATGTTCAATCGCATCAACG3' & 5'GGCTGATTCTTTTGCTTCAGG3' & 245 & XM_543068 \\
\hline Adiponectin & 5'TGGGATTGGAGAGTCGGGT3' & 5'ACTGGTCGTAGGTGAAGAGCA3' & 216 & AB115956 \\
\hline Leptin & 5'TAGCCACATCCCTTTGAAGCA3' & 5'АТTСАСАТСССТСАССТССТGЗ' & 243 & AB041360 \\
\hline 18S rRNA & $5^{\prime}$ CGAGCCGCCTGGATACC $^{\prime}$ & $5^{\prime}$ CCTCAGTTCCGAAAACCAACAA3' & 76 & M10098 \\
\hline
\end{tabular}

RIA $^{(31)}$. The measurements were made using bovine insulin, the first antibody being raised in guinea pigs and the second in goats. All the samples were processed in a single assay, and the detection limit was $9.83 \mathrm{ng} / \mathrm{ml}$. Six replicates of three control samples containing 60.23, 87.44 and $220.75 \mathrm{ng} / \mathrm{ml}$ were included in the assay, and were used to estimate the intra-assay $\mathrm{CV}$ of $5.7,2.8$ and $4.2 \%$, respectively. Plasma IGF-1 was assayed in duplicate using a double-antibody RIA with human recombinant IGF-1 (ARM4050; AmershamPharmacia Biotech, Little Chalfont, Bucks, UK) using rabbit antiserum and donkey antiserum following the protocol for acid-ethanol extraction and cryoprecipitation ${ }^{(32)}$. All the samples were processed in a single assay with a detection limit of $0.04 \mathrm{ng} / \mathrm{ml}$. The intra-assay coefficients were estimated from samples containing 0.33 and $2.09 \mathrm{ng} / \mathrm{ml}$, and were 11.0 and $4.9 \%$, respectively. All the assays were validated for mink. Serial dilutions of mink plasma containing high concentrations of the hormones leptin, insulin and IGF-1 produced curves parallel to the standard curves for the actual hormones.

\section{Statistical analysis}

The data were analysed for statistical significance using the mixed procedure in Statistical Analysis Software (SAS Institute, Cary, NC, USA) as repeated measurements ${ }^{(33)}$. Stage of gestation and foetal life protein provision were fixed effects in the model. The residuals of the data were normally distributed. Stage of gestation or lactation week was used as a repeated measure, and the autoregressive order 1 covariance structure was fitted ${ }^{(33)}$. The results were analysed in two separate analyses, gestation and lactation. Results are presented as least square means, and the square root of the residuals is given as the measure of variance for each variable. Pairwise comparisons of least square means were performed using the PDIFF option. Differences were denoted as significant, if $P<0 \cdot 05$, and as a tendency, if $P \leq 0 \cdot 10$.

\section{Results}

All results regarding nutrient intake and metabolic traits are given in relation to metabolic body size $\left(\mathrm{kg}^{-0.75}\right)$ to facilitate comparisons between animals at different stages of gestation and lactation.

\section{Reproductive performance and kit body weight}

Five of the twenty-three dams exposed to protein restriction and two of the thirty-three dams adequately nourished during foetal life were barren. Among the dams that did give birth, no significant differences were observed in terms of reproductive performance between the two in utero treatments (Table 2). The body weight at birth was significantly $(P=0 \cdot 003)$ higher among kits born to FLP1 than among kits born to FAP1 dams, and the differences between FLP2 and FAP2 kits remained significant $(P=0.04)$ until 7 d postpartum. Newborn males were $6.2 \%$ heavier than the females regardless of the protein provision during foetal life that their mothers were exposed to $(P=0.03)$, moreover, the males were still significantly $(P=0.03)$ heavier than the females at $28 \mathrm{~d}$ of age (Table 2$)$.

\section{Nutrient intake}

The feed and nutrient intake of the dams declined significantly $(P<0.01)$ from early to late gestation, with protein provision during foetal life having no effect.

A significant $(P<0.001)$ increase in feed and nutrient intake occurred between the second and fourth weeks of lactation, and FLP1 dams had a significantly higher intake of crude protein, fat, carbohydrates (all $P=0.03)$ and energy $(P=0.02)$ than did FAP1 dams in the fourth week of lactation.

\section{Nitrogen metabolism}

The diets early in life did not affect nitrogen metabolism during early and late gestation, but the ingested nitrogen, digested nitrogen and nitrogen excreted in the faeces and urine all decreased significantly from early to late gestation as feed intake decreased. Furthermore, nitrogen retention remained very stable throughout gestation, and included nitrogen for foetal growth (Table 3).

The digested nitrogen and the nitrogen excreted in faeces and urine increased between the second and fourth weeks of lactation as the intake of nitrogen increased. The calculated nitrogen excretion in milk also increased significantly $(P=0.03)$ between the second and fourth weeks of lactation. The calculated nitrogen retention (excluding nitrogen in milk) was negative throughout both the second and fourth weeks of lactation, indicating that the dams were mobilising body protein for milk production. Furthermore, FLP1 dams had a significantly $(P<0.05)$ higher intake of nitrogen and a higher rate of excretion of nitrogen in urine in the fourth week of lactation than FAP1 dams, a finding that corresponds with the higher feed and nitrogen intake (Table 3). 
Table 2. Reproductive performance of dams ( $F_{1}$ generation) either adequately nourished (FAP1) or exposed to a low protein provision during foetal life (FLP1) and the body weight of their offspring $\left(F_{2}\right.$ generation, FAP2 and FLP2) from birth until $28 \mathrm{~d}$ of age

\begin{tabular}{|c|c|c|c|c|c|c|c|c|}
\hline & \multicolumn{2}{|c|}{ Treatment } & \multicolumn{2}{|c|}{ Sex } & \multirow{2}{*}{$\mathrm{RR}$} & \multicolumn{3}{|c|}{$P$} \\
\hline & FAP1 & FLP1 & M & $\mathrm{F}$ & & $\mathrm{T}$ & G & $\mathrm{T} \times \mathrm{G}$ \\
\hline \multicolumn{9}{|c|}{ Reproductive performance ( $n$ 40) } \\
\hline Barren females (\%) & $6 \cdot 2$ & $21 \cdot 7$ & & & & & & \\
\hline Kits per litter & $6 \cdot 7$ & $7 \cdot 2$ & & & 0.7 & NS & & \\
\hline Live born kits per litter & $5 \cdot 2$ & $6 \cdot 2$ & & & $2 \cdot 6$ & NS & & \\
\hline Stillborn kits (\%) & $22 \cdot 4$ & 13.5 & & & $27 \cdot 4$ & NS & & \\
\hline Kits per mated female & $6 \cdot 3$ & $5 \cdot 6$ & & & $3 \cdot 2$ & NS & & \\
\hline Male kits (\%) & $51 \cdot 0$ & $44 \cdot 0$ & & & $20 \cdot 9$ & NS & & \\
\hline Female kits (\%) & $49 \cdot 0$ & $56 \cdot 0$ & & & $20 \cdot 9$ & NS & & \\
\hline Kit body weight (g, $n$ 248) & FAP2 & FLP2 & & & & & & \\
\hline Birth weight & $11 \cdot 1^{\mathrm{a}}$ & $12 \cdot 2^{b}$ & $12 \cdot 0^{\mathrm{a}}$ & $11 \cdot 3^{b}$ & $2 \cdot 2$ & 0.003 & 0.03 & NS \\
\hline $7 \mathrm{~d}$ & $34.2^{\mathrm{a}}$ & $36 \cdot 4^{\mathrm{b}}$ & $35 \cdot 8$ & 34.9 & 7.5 & 0.04 & NS & NS \\
\hline $14 d$ & $71 \cdot 8$ & 72.9 & $74 \cdot 5^{\mathrm{a}}$ & $70 \cdot 2^{\mathrm{b}}$ & 14.6 & NS & 0.04 & NS \\
\hline $21 d$ & $122 \cdot 0$ & $117 \cdot 8$ & $122 \cdot 6$ & $117 \cdot 2$ & $25 \cdot 2$ & NS & NS & NS \\
\hline $28 d$ & $184 \cdot 6$ & $176 \cdot 0$ & $185 \cdot 6^{\mathrm{a}}$ & $175 \cdot 0^{b}$ & $32 \cdot 2$ & 0.07 & 0.03 & NS \\
\hline
\end{tabular}

$M$, male; $F$, female; $R R$, square root of residuals; $T$, treatment during dam foetal life; $G$, sex

${ }^{\mathrm{a}, \mathrm{b}}$ Mean values within a row with unlike superscript letters were significantly different $(P<0.05)$.

Table 3. The body weight (BW), metabolisable energy (ME), heat production (HE), retained energy (RE), retained fat energy (RFE), energy in milk $(\mathrm{LE})$, digested nitrogen (DN), urinary nitrogen (UN), retained nitrogen (RN), nitrogen excreted in milk (LN) and the oxidation of protein (OXP), fat (OXF) and carbohydrates $(\mathrm{OXCHO})$ as a percentage of the heat production (HE) during gestation and lactation of dams exposed to either low (FLP1)- or adequate (FAP1)-protein diet during foetal life

(Mean values and standard deviations)

\begin{tabular}{|c|c|c|c|c|c|c|c|c|}
\hline & \multicolumn{4}{|c|}{ Gestation/lactation } & \multirow[b]{2}{*}{$\mathrm{RR}$} & \multicolumn{3}{|c|}{$P$} \\
\hline & Mean & SD & Mean & SD & & $S$ & $\mathrm{~T}$ & $\mathrm{~S} \times \mathrm{T}$ \\
\hline Days before partus ( $n 16)$ & 28 & 1.9 & 7 & 1.5 & & & & \\
\hline BW $(g)$ & $1075^{a}$ & & $1218^{\mathrm{b}}$ & & 116 & $<0.001$ & NS & NS \\
\hline $\mathrm{DN}\left(\mathrm{g} \mathrm{kg}^{-0.75}\right)$ & $2 \cdot 83^{a}$ & & $2 \cdot 08^{\mathrm{b}}$ & & 0.72 & 0.008 & NS & NS \\
\hline UN $\left(\mathrm{g} \mathrm{kg}^{-0.75}\right)$ & $2 \cdot 54^{\mathrm{a}}$ & & $1.50^{\mathrm{b}}$ & & 0.44 & $<0.001$ & NS & NS \\
\hline $\mathrm{RN}\left(\mathrm{g} \mathrm{kg}^{-0.75}\right)$ & 0.40 & & 0.58 & & 0.35 & NS & NS & NS \\
\hline $\mathrm{ME}\left(\mathrm{kJ} \mathrm{kg}^{-0.75}\right)$ & $831^{a}$ & & $697^{\mathrm{b}}$ & & 175 & 0.02 & NS & NS \\
\hline $\mathrm{HE}\left(\mathrm{kJ} \mathrm{kg}^{-0.75}\right)$ & 688 & & 754 & & 109 & 0.08 & NS & NS \\
\hline $\operatorname{RE}\left(\mathrm{kJ} \mathrm{kg}^{-0.75}\right)$ & $189^{\mathrm{a}}$ & & $-65^{\mathrm{b}}$ & & 204 & 0.003 & NS & NS \\
\hline $\operatorname{RFE}\left(\mathrm{kJ} \mathrm{kg}^{-0.75}\right)$ & $146^{\mathrm{a}}$ & & $-151^{b}$ & & 174 & $<0.001$ & NS & NS \\
\hline OXP (\% of $\mathrm{HE})$ & $43^{\mathrm{a}}$ & & $24^{\mathrm{b}}$ & & $8 \cdot 7$ & $<0.001$ & NS & NS \\
\hline OXF (\% of $\mathrm{HE})$ & $44^{\mathrm{a}}$ & & $69^{b}$ & & $16 \cdot 7$ & $<0.01$ & NS & NS \\
\hline $\mathrm{OXCHO}(\%$ of $\mathrm{HE})$ & 12 & & 7 & & $10 \cdot 3$ & NS & NS & NS \\
\hline Week of lactation & 2 & & 4 & & & & & \\
\hline Live weight $(\mathrm{g})$ & $993^{\mathrm{a}}$ & & $958^{\mathrm{b}}$ & & 106 & 0.03 & NS & NS \\
\hline Average daily gain (g) & $-9 \cdot 5^{a}$ & & $-1 \cdot 7^{b}$ & & $7 \cdot 2$ & 0.02 & NS & NS \\
\hline DN $\left(\mathrm{g} \mathrm{kg}^{-0.75}\right)$ & $3.88^{\mathrm{a}}$ & & $6 \cdot 40^{\mathrm{b}}$ & & 0.85 & $<0.001$ & NS & 0.07 \\
\hline UN $\left(\mathrm{g} \mathrm{kg}^{-0.75}\right)$ & $2 \cdot 65^{a}$ & & $4 \cdot 32^{\mathrm{b}}$ & & 0.64 & $<0.001$ & NS & 0.04 \\
\hline $\mathrm{RN}\left(\mathrm{g} \mathrm{kg}^{-0.75}\right)$ & $-0.45^{a}$ & & $-0.25^{b}$ & & 0.52 & NS & NS & NS \\
\hline $\operatorname{LN}\left(\mathrm{g} \mathrm{kg}^{-0.75}\right)$ & 1.67 & & $2 \cdot 32^{\mathrm{b}}$ & & 0.59 & $<0.001$ & NS & NS \\
\hline ME per dam $\left(\mathrm{kJ} \mathrm{kg}^{-0.75}\right)$ & & & & & 242 & $<0.001$ & NS & 0.02 \\
\hline FAP1 & $1192^{\mathrm{a}}$ & & $1816^{\mathrm{b}, \mathrm{A}}$ & & & & & \\
\hline FLP1 & $1237^{\mathrm{a}}$ & & $2082^{\mathrm{b}, \mathrm{B}}$ & & & & & \\
\hline $\mathrm{HE}\left(\mathrm{kJ} \mathrm{kg}^{-0.75}\right)$ & 656 & & 687 & & 143 & NS & NS & NS \\
\hline LE $\left(\mathrm{kJ} \mathrm{kg}^{-0.75}\right)$, calculated & $766^{\mathrm{a}}$ & & $1099^{b}$ & & 269 & 0.003 & NS & NS \\
\hline $\mathrm{RE}\left(\mathrm{kJ} \mathrm{kg}^{-0.75}\right)$, calculated & & & & & 218 & $<0.001$ & NS & 0.1 \\
\hline FAP1 & $-222^{a}$ & & $4^{b}$ & & & & & \\
\hline FLP1 & $-209^{a}$ & & $247^{\mathrm{b}}$ & & & & & \\
\hline OXP ( $\%$ of $\mathrm{HE})$ & 25 & & 28 & & $3 \cdot 3$ & NS & NS & NS \\
\hline OXF (\% of HE) & 74 & & 71 & & $3 \cdot 6$ & NS & 0.08 & NS \\
\hline $\mathrm{OXCHO}(\%$ of $\mathrm{HE})$ & 0 & & 2 & & $2 \cdot 2$ & NS & NS & NS \\
\hline
\end{tabular}

$\mathrm{RR}$, square root of residuals; $\mathrm{S}$, stage of gestation and week of lactation; $\mathrm{T}$, treatment during dam foetal life.

$\mathrm{a}, \mathrm{b}$ Mean values within a row with unlike lower case superscript letters were significantly different $(P<0.05)$.

$\mathrm{A}, \mathrm{B}$ Mean values within a column with unlike upper case superscript letters were significantly different $(P<0.05)$. 


\section{Energy metabolism and body weight}

The overall energy metabolism of the dams was not affected by the level of protein provision during foetal life, but rather by the stage of gestation. The intake of ME declined by $16 \%$ from early to late gestation $(P=0.02)$, whereas the heat production increased by $9.6 \%(P=0.08)$ over the same period. Both the retained energy $(P=0.003)$ and the energy retained from fat $(P<0.001)$ declined from positive values early in gestation to negative values in late gestation, whereas the body weight increased by $13 \%$ from early to late gestation $(P<0 \cdot 001)$ as a result of increasing foetal growth (Table 3$)$.

The ME intake increased significantly $(P<0 \cdot 001)$ between the second and fourth weeks of lactation, and was significantly higher among FLP1 dams than among FAP1 dams in the fourth week of lactation. A significant, $43.5 \%$ increase in the estimated energy excreted in milk was observed between the second and fourth weeks of lactation (Table 3).

\section{The substrate oxidation}

Substrate oxidation was not affected by protein supply during foetal life, but oxidation of protein decreased (43 v. $24 \%$, $P<0.001$ ) and oxidation of fat increased (44 v. $69 \%$, $P<0.01)$ significantly, while oxidation of carbohydrates did not change significantly from early to late gestation (Table 3 ).

The oxidation of protein, fat and carbohydrate was affected by neither maternal protein provision during foetal life nor stage of lactation (Table 3). However, there was a tendency $(P=0.08)$ towards higher oxidation of fat as a percentage of heat production among FAP1 dams than among FLP1 dams. Virtually, no carbohydrate was oxidised, indicating that the entire carbohydrate intake was used for milk synthesis.

\section{Plasma hormone concentration}

There was a decline in the plasma concentration of leptin (27\%,P=0.03), insulin (38\%,P=0.002) and IGF-1 (22\%, $P=0.001$ ) from early to late gestation (Fig. 2(a) and (b)). Furthermore, there were tendencies towards $26 \%$ higher concentration of insulin $(P=0.09)$ and $10 \%$ higher concentration of IGF-1 $(P=0 \cdot 1)$ among FAP1 dams than among FLP1 dams during gestation.

The plasma concentrations of leptin, insulin and IGF-1 throughout the lactation period was not affected by protein supply during foetal life, but rather increased by 13, 14 and $4 \%$, respectively, between the second and fourth weeks of lactation, although these differences proved to be non-significant (Fig. 2(a) and (b)).

\section{Late gestation tissue collection data}

Liver weight in relation to body weight was not significantly affected by protein supply during early life. No significant differences in uterus weight or number of foetuses were found between the two treatment groups. The liver weight as well as foetal weight and length (FLP2 and FAP2) were not affected by the dam's protein provision during early life. However, foetal length and weight were significantly affected by the time interval from mating to euthanasia, which
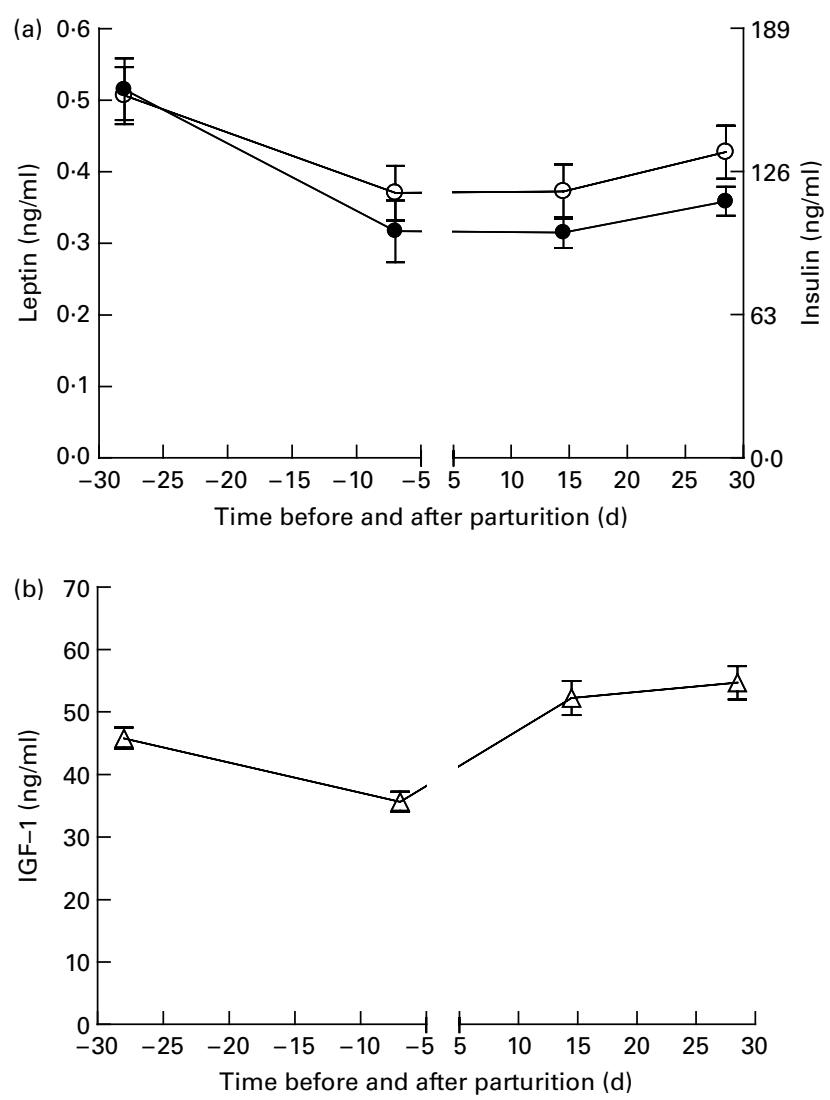

Fig. 2. The plasma concentration of (a) leptin $(\bigcirc, \mathrm{ng} / \mathrm{ml})$ and insulin $(\bullet, \mathrm{ng} / \mathrm{ml})$; (b) insulin-like growth factor $1(\Delta, \mathrm{GGF}-1, \mathrm{ng} / \mathrm{ml})$ in sixteen dams; eight were exposed to low protein supply (FLP1), and eight were given adequate protein supply (FAP1) during foetal life. The dams were blood-sampled in early (28 (SD 1.9) d before parturition) and late gestation (7 (SD 1.5) d before parturition), and twelve dams were blood-sampled during the second and fourth weeks of lactation. Mean values are shown with their standard errors represented by vertical bars. The plasma concentration was not affected by the two different protein supplies during foetal life, and therefore given as an overall mean.

indicates that the dams might have been at different stages of true gestation when tissue was collected (Table 4).

\section{Gene expression in hepatic and adipose tissue}

The abundance of $\mathrm{PKM}_{2}$ mRNA $(P=0.04)$ and Fru-1,6- $\mathrm{P}_{2}$ ase mRNA $(P=0.04)$ relative to that of $18 \mathrm{~s}$ rRNA was significantly lower in dams than in their foetuses. Glucose6-phosphatase $(P=0.04)$ and phosphoenolpyruvate carboxykinase $(P=0 \cdot 02)$ were found to be expressed in foetal hepatic tissue, but at levels significantly lower than those in dam hepatic tissue. No significant differences were found in the expression of Fru-1,6- $\mathrm{P}_{2}$ ase, $\mathrm{PKM}_{2}$, phosphoenolpyruvate carboxykinase or glucose-6-phosphatase between FAP1 and FLP1 dams. The gene expression of leptin and adiponectin mRNA in the adipose tissue of the FLP1 and FAP1 dams was not significantly affected by protein provision during early life. The relative abundance of $\mathrm{PKM}_{2}$ mRNA was significantly $(P=0.007)$ lower in hepatic tissue from FLP2 foetuses than in that from FAP2 foetuses, and there was a tendency $(P=0.08)$ for a lower gene expression of 
Table 4. Liver and uteri weights, number of foetuses and plasma concentrations of leptin, insulin and insulin-like growth factor (IGF-1) of dams exposed to either adequate protein (FAP1) or low protein supply (FLP1) during foetal life and euthanised in late gestation, and the body weight, length and liver weights of their foetuses (FAP2 and FLP2)

\begin{tabular}{|c|c|c|c|c|c|c|}
\hline & \multicolumn{2}{|c|}{ Treatment } & \multirow[b]{2}{*}{$\mathrm{RR}$} & \multicolumn{3}{|c|}{$P$} \\
\hline & FAP1 & FLP1 & & $\mathrm{T}$ & Time & $T \times$ time \\
\hline \multicolumn{7}{|l|}{ Dams $(n 8)$} \\
\hline Liver $\left(\mathrm{g} \mathrm{kg}^{-0.75}\right)$ & 34.9 & 32.5 & $5 \cdot 3$ & NS & NS & NS \\
\hline Liver (\% of LW) & $3 \cdot 2$ & $3 \cdot 1$ & 0.5 & NS & NS & NS \\
\hline Uterus $(\mathrm{g})$ & $101 \cdot 7$ & 103.9 & 35.4 & NS & NS & NS \\
\hline Number of foetuses (live) & & & $2 \cdot 6$ & NS & NS & NS \\
\hline Time 1 & $11 \cdot 0$ & $9 \cdot 0$ & & & & \\
\hline Time 2 & $5 \cdot 0$ & $7 \cdot 0$ & & & & \\
\hline Insulin $\left(\mu \cup \mathrm{ml}^{-1}\right)$ & $3 \cdot 27$ & 2.43 & 1.03 & NS & NS & NS \\
\hline IGF1 (ng ml $\left.{ }^{-1}\right)$ & 65.40 & $66 \cdot 00$ & $13 \cdot 25$ & NS & NS & NS \\
\hline Leptin $\left(\mathrm{ng} \mathrm{ml}^{-1}\right)$ & 0.29 & 0.26 & 0.07 & NS & NS & NS \\
\hline Litters $(n 8)$ & FAP2 & FLP2 & & & & \\
\hline Foetus liver $\left(\mathrm{g} \mathrm{kg}^{-0.75}\right)$ & & & $2 \cdot 3$ & NS & NS & 0.06 \\
\hline Time 1 & $25 \cdot 9^{\mathrm{A}}$ & 24.4 & & & & \\
\hline Time 2 & $19 \cdot 3^{a, B}$ & $26 \cdot 6^{\mathrm{b}}$ & & & & \\
\hline Length of foetuses (mm) & & & $5 \cdot 2$ & NS & 0.007 & NS \\
\hline Time 1 & $35 \cdot 1^{\mathrm{A}}$ & $34.9^{\mathrm{A}}$ & & & & \\
\hline Time 2 & $69 \cdot 0^{\mathrm{B}}$ & $55 \cdot 6^{\mathrm{B}}$ & & & & \\
\hline Weight of foetuses $(\mathrm{g})$ & & & $2 \cdot 0$ & 0.1 & 0.01 & 0.1 \\
\hline Time 1 & $2 \cdot 3^{\mathrm{A}}$ & $2 \cdot 2$ & & & & \\
\hline Time 2 & $11 \cdot 2^{\mathrm{a}, \mathrm{B}}$ & $5 \cdot 3^{b}$ & & & & \\
\hline
\end{tabular}

Fru-1,6- $\mathrm{P}_{2}$ ase mRNA in hepatic tissue from FLP2 foetuses than in that from FAP2 foetuses (Table 5).

\section{Discussion}

The present study has revealed that some changes in metabolic regulation caused by protein restriction during late gestation can be detected in subsequent generations in the mink. This confirms that, similar to other species ${ }^{(5-7,9,34)}$, the provision of a low level of protein during early life can have implications for the progeny in mink. Moreover, these findings extend the research of our group, which has previously investigated the effect of protein restriction during late gestation on reproductive performance, birth weight, energy and protein metabolism traits, quantitative gene expression encoding for enzymes involved in gluconeogenesis and glycolysis, and metabolic hormones in mink dams and their foetuses ${ }^{(19)}$.

\section{Reproductive performance, litter size and body weight}

The higher birth weight of the $\mathrm{F}_{2}$ generation offspring is similar to some findings for rats, where the birth weight of pups born to dams exposed to protein restriction during foetal life was $11.6 \%$ (females) and $14.7 \%$ (males) higher than that of

Table 5. The relative abundances of glucose-6-phophatase (G-6-Pase), fructose-1,6-bisphosphatase (Fru-1,6- $\mathrm{P}_{2}$ ase), phosphoenolpyruvate carboxykinase (PEPCK) and pyruvate kinase $\left(\mathrm{PKM}_{2}\right) \mathrm{mRNA}$ normalised to $18 \mathrm{~s}$ rRNA in the hepatic tissue of dams ( $F_{1}$ generation) exposed to either low (FLP1) or adequate protein (FAP1) provision during early life and their foetuses $\left(F_{2}\right.$ generation, FLP2 and FAP2) ${ }^{\star}$

\begin{tabular}{|c|c|c|c|c|c|c|c|c|}
\hline \multirow{2}{*}{$n 16$} & \multicolumn{4}{|c|}{ Type of animal } & \multirow[b]{2}{*}{$\mathrm{RR}$} & \multicolumn{3}{|c|}{$P$} \\
\hline & \multicolumn{2}{|c|}{ Dam } & \multicolumn{2}{|c|}{ Foetus } & & TA & $\mathrm{T}$ & $\mathrm{TA} \times \mathrm{T}$ \\
\hline G-6-Pase & \multicolumn{2}{|c|}{$12 \cdot 5^{\mathrm{a}}$} & \multicolumn{2}{|c|}{$6 \cdot 4^{b}$} & 5.5 & 0.04 & NS & NS \\
\hline \multirow{2}{*}{ PEPCK } & \multicolumn{2}{|c|}{$2 \cdot 7^{\mathrm{a}}$} & \multicolumn{2}{|c|}{$0.4^{\mathrm{b}}$} & 1.6 & 0.02 & NS & NS \\
\hline & FAP1 & FLP1 & FAP2 & FLP2 & & & & \\
\hline $\mathrm{PKM}_{2}$ & $0.9^{\mathrm{a}, \mathrm{c}}$ & $1 \cdot 1^{\mathrm{a}, \mathrm{c}}$ & $10 \cdot 3^{b}$ & $4 \cdot 4^{c}$ & $2 \cdot 1$ & $<0.001$ & 0.04 & 0.03 \\
\hline Fru-1,6- $\mathrm{P}_{2}$ ase & $\begin{array}{l}2 \cdot 6^{\mathrm{a}} \\
\text { FAP1 }\end{array}$ & $\begin{array}{l}1.4^{\mathrm{a}} \\
\text { FLP1 }\end{array}$ & $5 \cdot 6^{\mathrm{b}}$ & $3 \cdot 0^{\mathrm{a}}$ & $1 \cdot 7$ & 0.04 & 0.07 & NS \\
\hline Adiponectin & 0.2 & 0.2 & & & $0 \cdot 1$ & NS & NS & NS \\
\hline Leptin & $2 \cdot 6$ & 3.7 & & & $2 \cdot 7$ & NS & NS & NS \\
\hline
\end{tabular}

$\mathrm{RR}$, square root of residuals; TA, type of animal; $\mathrm{T}$, treatment.

a,b Mean values within a row with unlike lower case superscript letters were significantly different $(P<0.05)$.

${ }^{*}$ The relative abundance of leptin and adiponectin mRNA normalised to 18s rRNA in subcutaneous adipose tissue in dams exposed to either low (FLP1) or adequate protein (FAP1) provision during foetal life. 
pups born to dams provided with an adequate level of protein during foetal life ${ }^{(5)}$. However, others have only found a higher body weight at birth among $F_{2}$ generation females, and not among males ${ }^{(7)}$. Moreover, it should be said that these findings stand in contrast to those of others with rats, in which the birth weight of the $\mathrm{F}_{2}$ generation did not differ from that of controls ${ }^{(35)}$, or was significantly lower than that of controls. There is evidence that dams that have been exposed to protein or energy restriction in utero become glucose intolerant or hyperglycaemic when they are pregnant ${ }^{(36)}$; this matter, however, was not investigated in the present experiment. It has previously been hypothesised that increased birth weight or foetal macrosomia in the offspring of diabetic mothers could result from hyperinsulinaemia in response to maternal hyperglycaemia and thereby increased foetal growth ${ }^{(37)}$. Our yearling dams did, however, rather have a tendency towards lower plasma insulin levels than controls. This in itself is interesting as others have found that low pancreatic insulin secretion, as a result of low maternal protein supply, leads to gestational diabetes and hyperglycaemia ${ }^{(38,39)}$. Such an intrauterine hyperglycaemic environment stimulates the endocrine pancreas in foetuses born to these dams, resulting in an increased insulin production and an accelerated anabolism, which together lead to enhanced foetal growth and macrosomia ${ }^{(40)}$. This phenomenon could help explain the increased birth weight observed in the present study in the $\mathrm{F}_{2}$ generation offspring born to FLP1 dams, and furthermore, be supported by the tendency for FLP1 dams to have a lower plasma insulin level during gestation than FAP1 dams. Whether the higher birth weight of the FLP2 kits was caused by maternal hyperglycaemia or whether it also depends on when in gestation or lactation the protein provision is restricted in the previous generation needs further investigation.

\section{Energy and protein metabolism}

The significantly higher feed intake and thereby nutrient and ME intake of the FLP1 dams than of FAP1 dams throughout lactation are consistent with the original idea of induced changes caused by maternal malnutrition, leading to thriftiness later in life, as characterised by enhanced nutrient uptake and storage in the body ${ }^{(41)}$. The other measured energy and protein metabolism traits, however, were not affected by protein provision during foetal life. Although measurements were only made during early and late gestation, and throughout the second and fourth weeks of lactation, one cannot exclude the possibility that effects could have been detected at other stages of the reproductive cycle. Moreover, the issue of a larger sample size and thereby that of a greater level of sensitivity remain unresolved, due to the limited foetal material available from this particular species.

\section{Plasma hormone concentrations}

It has been demonstrated previously ${ }^{(24)}$ that plasma leptin increased during the last third of the true gestation despite a decline in feed intake, unlike the normal response of leptin to reduced food intake in non-pregnant $\operatorname{mink}^{(42)}$. It was not possible to confirm these findings in the present experiment because plasma leptin was only measured twice: once in early question and once in late gestation. However, a decline in feed intake from early to late gestation is in agreement with others $^{(24)}$. The tendency towards lower plasma insulin concentrations among the FLP1 dams than among the FAP1 dams during gestation could, because of similar feed intake between the two treatments during adult life, indicate that the endocrine pancreas was affected by protein restriction during early life, so it is possible that the FLP1 dams were somewhat hyperglycaemic. This corresponds with findings in foetal life proteinrestricted pregnant rats where some changes in the endocrine pancreas remained through to adult $\operatorname{life}^{(38)}$. In this particular case, it led to glucose intolerance, especially during pregnancy, and resulted in gestational diabetes as a consequence of the hyperglycaemia ${ }^{(38)}$. This is supported by others showing that the endocrine pancreas is altered by maternal protein restriction that leads to a reduction in $\beta$-cell mass ${ }^{(43)}$ and islet size, especially in the head of the pancreas, and poor subsequent insulin secretion ${ }^{(44,45)}$, but only if the low protein supply was maintained after birth ${ }^{(38)}$. Nutritional supplementation later in life increases, but never fully restores, $\beta$-cell proliferation $^{(46)}$. The present material, however, does not allow for firm conclusions to be drawn because the plasma glucose concentrations and the morphology of the pancreas were not investigated.

Gene expression of key hepatic glycolytic and gluconeogenic enzymes

Unlike the findings for FLP1 and FAP1 foetuses in our previous study ${ }^{(19)}$, we did not find less Fru-1,6- $\mathrm{P}_{2}$ ase and $\mathrm{PKM}_{2}$ mRNA in the hepatic tissue of the 1-year-old FLP1 dams compared with the 1-year-old FAP1 dams. Whether the observed gene expression changes in foetal hepatic tissue were alleviated by adequate feeding, or whether the downregulation is only detectable during foetal life, now needs to be the focus of further investigation. Despite the only difference in energy and nitrogen metabolism traits being a higher intake of ME in the fourth week of lactation among the 1-year-old FLP1 dams, and differences in the expression of selected gluconeogenic and glycolytic enzymes being non-significant, the expression of $\mathrm{PKM}_{2}$ was still significantly lower and that of fructose-1,6-bisphosphatase ${ }_{2}$ ase tended to be lower in the FLP2 foetuses than in the FAP2 foetuses. These findings could indicate maternal transmission of either epigenetic, e.g. changes in DNA methylation, or nonepigenetic changes from the $F_{1}$ to $F_{2}$ generation foetuses, despite the provision of an adequate level of nutrition to the $F_{1}$ generation dams from birth and throughout their own gestation. Such non-epigenetic changes could simply be a result of an adjustment in the foetus in response to a diabetic environment. Evidence that nutritionally induced changes in glucose metabolism can be transgenerational from the $\mathrm{F}_{1}$ generation to the $F_{2}$ generation $^{(5)}$, and even up to the $F_{3}$ generation $^{(9)}$, have also been found in rats. However, the changes induced by malnutrition during foetal life in mink differ from those in rats: in rats ${ }^{(10)}$, but not in mink, phosphoenolpyruvate carboxykinase, the only enzyme analysed both here and in earlier rat experiments, was upregulated by low maternal protein supply in both the $F_{1}$ and $F_{2}$ generations, though the effect might be sex specific ${ }^{(6)}$ or due to differences in the level and time of protein restriction in the mother ${ }^{(2)}$. Presently, the consequence of the changes in gene expression found in 
the present study is unknown, but might, if the postnatal environment differs from that experienced during prenatal life, be a disadvantage for long-term animal health and performance.

\section{Conclusion}

Malnutrition during late gestation in the $F_{0}$ generation and thereby malnutrition during foetal life of the $F_{1}$ generation lead to a higher birth weight of the $F_{2}$ generation offspring despite provision of an adequate level of nutrition to the $F_{1}$ generation from birth and thereafter. Our experiment also confirms that changes in hepatic enzymes, induced by malnutrition during foetal life of the $\mathrm{F}_{1}$ generation, are transgenerational, and therefore detectable in the $F_{2}$ generation in mink. These findings indicate that even though most metabolism traits display no effect of protein provision during early life, nutritionally induced effects still appear at the molecular level in the subsequent generation. It is now important that these findings be explored in a human perspective bearing in mind that malnutrition during pregnancy might lead to transgenerational changes. Indeed, the mink, due to its spontaneous insulin resistance, may prove to be a useful animal model in studies of obesity and type 2 diabetes. Finally, another potentially important perspective that arises from the present study is that of the design of diets for the optimal breeding of companion animals requiring a high daily protein intake, i.e. cats and dogs.

\section{Acknowledgements}

The authors gratefully acknowledge the financial support for this research given by the Danish Food Industry Agency of the Ministry of Food, Agriculture and Fisheries. The present study was part of the research programme 'Interdisciplinary animal research', grant no. 5414114.95.304. Skilful technical assistance with collection routines and chemical analyses was provided by Merethe Stubgaard, Lotte Ørbæk and Ebba de Neergaard Harrison, with animal handling by Boye Pedersen, respiration unit operation by Abdalla Ali, RIA measurements by Margaret Blackberry and quantitative PCR work undertaken by Anne Friis Petersen and Kristine Vesterdorf. C. F. M. performed the hormone assays and quantitative PCR work, conducted the data analysis and wrote the paper. D. B. supervised the hormone assays, and has critically reviewed the manuscript. $\mathrm{P}$. D. T. supervised the quantitative PCR work, and critically reviewed the manuscript. A.-H. T., supervisor of C. F. M., led and designed the study, as well as critically discussed and reviewed the manuscript. The authors state that there are no conflicts of interest.

\section{References}

1. Hales CN \& Barker DJP (1992) Type 2 (non-insulin-dependent) diabetes mellitus: the thrifty phenotype hypothesis. Diabetologia 35, 595-601.

2. McMillen IC \& Robinson JS (2005) Developmental origins of the metabolic syndrome: prediction, plasticity, and programming. Physiol Rev 85, 571-633.

3. Lucas A (1991) Programming by early nutrition in man. In The Childhood Environment and Adult Disease - Ciba Foundation
Symposium 156, pp. 38-55 [GR Bock and J Whelan, editors]. Chichester: John Wiley \& Sons Ltd.

4. Gluckman PD \& Hanson MA (2004) Living with the past: evaluation, development, and patterns of disease. Science 305, 1733-1736.

5. Pinheiro AR, Salvucci IDM, Aguila MB, et al. (2008) Protein restriction during gestation and/or lactation causes adverse transgenerational effects on biometry and glucose metabolism in $F_{1}$ and $F_{2}$ progenies of rats. Clin Sci 114, 381-392.

6. Burdge GC, Slater-Jefferies J, Torrens C, et al. (2007) Dietary protein restriction of pregnant rats in the $\mathrm{F}_{0}$ generation induces altered methylation of hepatic gene promoters in the adult male offspring in the $\mathrm{F}_{1}$ and $\mathrm{F}_{2}$ generations. Br J Nutr 97, 435-439.

7. Zambrano E, Martinez-Samayoa PM, Bautista CJ, et al. (2005) Sex differences in transgenerational alterations of growth and metabolism in progeny $\left(\mathrm{F}_{2}\right)$ of female offspring $\left(\mathrm{F}_{1}\right)$ of rats fed a low protein diet during pregnancy and lactation. $J$ Physiol 566, 225-236.

8. Benyshek DC, Johnston CS \& Martin JF (2004) Post-natal diet determines insulin resistance in fetally malnourished, low birthweight rats $\left(\mathrm{F}_{1}\right)$ but diet does not modify the insulin resistance of their offspring $\left(\mathrm{F}_{2}\right)$. Life Sci 74, 3033-3041.

9. Benyshek D, Johnston C \& Martin J (2006) Glucose metabolism is altered in the adequately-nourished grand-offspring $\left(\mathrm{F}_{3}\right.$ generation) of rats malnourished during gestation and perinatal life. Diabetologia 49, 1117-1119.

10. Desai M, Byrne CD, Zhang J, et al. (1997) Programming of hepatic insulin-sensitive enzymes in offspring of rat dams fed a protein-restricted diet. Am J Physiol 272, G1083-G1090.

11. Ozanne SE \& Hales CN (1999) The long-term consequences of intra-uterine protein malnutrition for glucose metabolism. Proc Nutr Soc 58, 615-619.

12. Desai M, Crowther NJ, Lucas A, et al. (1996) Organ-selective growth in the offspring of protein-restricted mothers. $\mathrm{Br} J$ Nutr 76, 591-603.

13. Burns SP, Desai M, Cohen RD, et al. (1997) Gluconeogenesis, glucose handling, and structural changes in livers of the adult offspring of rats partially deprived of protein during pregnancy and lactation. J Clin Invest 100, 1768-1774.

14. Ozanne SE \& Hales CN (2002) Early programming of glucoseinsulin metabolism. Trends Endocrinol Metab 13, 368-373.

15. Garofano A, Czernichow P \& Breant B (1997) In utero undernutrition impairs rat beta-cell development. Diabetologia $\mathbf{4 0}$, $1231-1234$.

16. Venge O (1973) Reproduction in the mink. Copenhagen: Royal Veterinary and Agricultural University pp. 95-146.

17. Tauson A-H, Elnif J \& Hansen NE (1992) Energy metabolism and foetal growth in pregnant mink (Mustela vison). Norw $J$ Agric Sci Suppl. 9, 261-267.

18. Bouchard GF \& Sunvold GD (2000) Effect of dietary carbohydrate source on postprandial plasma glucose and insulin concentrations in cats. In Recent Advances in Canine and Feline Nutrition, Iams Nutrition Symposium Proceedings, vol. 3, pp. 91-101 [IGA Reinhart and DP Carey, editors] Wilmington, $\mathrm{OH}$ : Orange Frazer Press.

19. Matthiesen CF, Blache D, Thomsen PD, et al. (2010) Effect of late gestation low protein supply to mink (Mustela vison) dams on reproductive performance and metabolism of dam and offspring. Arch Anim Nutr 64, 56-76.

20. Anonymous (1986) European Convention for Protection of Vertebrate Animals Used for Experimental and other Scientific Purposes. Strasburg, Council of Europe. European Treaty Series No. 123.

21. Nes N, Einarsson EJ \& Lohi O (1987) Beautiful Fur Animals And Their Colour Genetics. Denmark: Scientifur Hillerød.

22. Elofson L, Lagerkvist G, Gusstafsson H, et al. (1989) Mating systems and reproduction in mink. Acta Agric Scand 39, 23-41. 
23. Jørgensen G \& Glem-Hansen N (1973) A cage designed for metabolism- and nitrogen balance trails with mink. Acta Agric Scand 23, 3-4.

24. Tauson AH, Forsberg M \& Chwalibog A (2004) High leptin in pregnant mink (Mustela vison) may exert anorexigenic effects: a permissive factor for rapid increase in food intake during lactation. Br J Nutr 91, 411-421.

25. Chwalibog A, Tauson AH \& Thorbek G (2004) Energy metabolism and substrate oxidation in pigs during feeding, starvation and re-feeding. J Anim Physiol Anim Nutr 88, 101-112.

26. Blixenkrone-Møller M, Lund E, Mikkelsen G, et al. (1987) Blood collection in mink. Scand J Lab Anim Sci 14, 99.

27. Brouwer E (1965) Report of Sub-committe on Constants and Factors. Eaap Publication no. 11. London: Academic Press.

28. Chwalibog A, Jakobsen K, Henckel S, et al. (1992) Estimation of quantitative oxidation and fat retention from carbohydrate, protein and fat in growing pigs. J Anim Physiol Anim Nutr 68, $123-135$.

29. Tauson AH, Fink R, Hansen KB, et al. (2004) Utilization of milk energy by suckling mink kits. Arch Anim Nutr 58, 181-194.

30. Blache D, Tellam RL, Chagas LM, et al. (2000) Level of nutrition affects leptin concentrations in plasma and cerebrospinal fluid in sheep. J Endocrinol 165, 625-637.

31. Tindal JS, Knaggs GS, Hart IC, et al. (1978) Release of growth hormone in lactating and non-lactating goats in relation to behaviour, stages of sleep, electroencephalograms, environmental stimuli and levels of prolactin, insulin, glucose and free fatty acids in the circulation. $J$ Endocrinol 76, 333-346.

32. Breier BH, Gallaher BW \& Gluckman PD (1991) Radioimmunoassay for insulin-like growth factor-I: solutions to some potential problems and pitfalls. $J$ Endocrinol 128, $347-357$.

33. Littell RC, Milliken GA \& Stroup WW (2006) SAS for Mixed Models, 2nd ed. Cary, NC: SAS Institute Inc.

34. Martin JF, Johnston CS \& Han CT (2000) Nutritional origins of insulin resistance: a rat model for diabetes-prone human populations. J Nutr 130, 741-744.
35. Torrens C, Poston L \& Hanson MA (2008) Transmission of raised blood pressure and endothelial dysfunction to the $F_{2}$ generation induced by maternal protein restriction in the $F_{0}$, in the absence of dietary challenge in the $\mathrm{F}_{1}$ generation. $\mathrm{Br} \mathrm{J}$ Nutr 100, 760-766.

36. Remacle C, Dumortier O, Bol V, et al. (2007) Intrauterine programming of the endocrine pancreas. Diabetes Obes Metab 9, 196-209.

37. Hattersley AT, Beards F, Ballantyne E, et al. (1998) Mutations in the glucokinase gene of the fetus result in reduced birth weight. Nat Genet 19, 268-270.

38. Dahri S, Reusens B, Remacle C, et al. (1995) Nutritional influences on pancreatic development and potential links with noninsulin-dependent diabetes. Proc Nutr Soc 54, 345-356.

39. Taricco E, Radaelli T, Nobilede Santis MS, et al. (2003) Foetal and placental weights in relation to maternal characteristics in gestational diabetes. Placenta 24, 343-347.

40. Aerts L \& Van Assche FA (2003) Intra-uterine transmission of disease. Placenta 24, 905-911.

41. Souza-Mello V, Mandarim-de-Lacerda CA \& Aguila M (2007) Hepatic structural alteration in adult programmed offspring (severe maternal protein restriction) is aggravated by postweaning high-fat diet. Br J Nutr 98, 1159-1169.

42. Tauson A-H \& Forsberg M (2002) Body-weight changes are clearly reflected in plasma concentrations of leptin in female mink (Mustela vison). Br J Nutr 87, 101-105.

43. Reusens B \& Remacle C (2006) Programming of the endocrine pancreas by the early nutritional environment. Int $J$ Biochem Cell Biol 38, 913-922.

44. Snoeck A, Remacle C, Reusens B, et al. (1990) Effect of a low protein diet during pregnancy on the fetal rat endocrine pancreas. Biol Neonate 57, 107-118.

45. Fowden AL \& Hill DJ (2001) Intra-uterine programming of the endocrine pancreas. Br Med Bull 60, 123-142.

46. Garofano A, Czernichow P \& Breant B (1998) Beta-cell mass and proliferation following late fetal and early postnatal malnutrition in the rat. Diabetologia 41, 1114-1120. 